\title{
Impact of changing DOC concentrations on the potential distribution of acid sensitive biota in a boreal stream network
}

\author{
H. Laudon ${ }^{1}$ and I. Buffam ${ }^{2}$ \\ ${ }^{1}$ Department of Ecology and Environmental Sciences, Umeå University, Umeå, Sweden \\ ${ }^{2}$ Department of Forest Ecology, Swedish University of Agricultural Sciences, Umeå, Sweden \\ Received: 2 November 2006 - Published in Hydrol. Earth Syst. Sci. Discuss.: 11 September 2007 \\ Revised: 28 November 2007 - Accepted: 5 February 2008 - Published: 5 March 2008
}

\begin{abstract}
DOC concentrations have increased in many surface waters in Europe and North America over the past few decades. As DOC exudes a strong influence on $\mathrm{pH}$ this DOC increase could have detrimental effects on acid sensitive biota in many streams and lakes. To investigate the potential implications of changes in the DOC concentration on stream water biota, we have used a mesoscale boreal stream network in northern Sweden as a case study. The network was sampled for stream water chemistry at 60 locations during both winter base flow and spring flood periods, representing the extremes experienced annually in these streams both in terms of discharge and acidity. The effect of changing DOC on $\mathrm{pH}$ was modeled for all sampling locations using an organic acid model, with input DOC concentrations for different scenarios adjusted by between $-30 \%$ and $+50 \%$ from measured present concentrations. The resulting effect on $\mathrm{pH}$ was then used to quantify the proportion of stream length in the catchment with $\mathrm{pH}$ below the acid thresholds of $\mathrm{pH} 5.5$ and $\mathrm{pH}$ 5.0. The results suggest that a change in stream water DOC during base flow would have only a limited effect on $\mathrm{pH}$ and hence on the stream length with $\mathrm{pH}$ below the acid thresholds. During the spring flood on the other hand a change in DOC would strongly influence $\mathrm{pH}$ and the stream length with $\mathrm{pH}$ below the acid thresholds. For example an increase in DOC concentration of $30 \%$ at all sites would increase the proportion of stream length with $\mathrm{pH}$ below 5.5 from $37 \%$ to $65 \%$, and the proportion of stream length with $\mathrm{pH}$ below 5.0 would increase from $18 \%$ to $27 \%$. The results suggest that in high DOC waters, even a marginal change in the DOC concentration could impact acid sensitive biota in a large portion of the aquatic landscape.
\end{abstract}

Correspondence to: H. Laudon

(hjalmar.laudon@emg.umu.se)

\section{Introduction}

The snow melt period is a recurring ecological challenge for aquatic organisms in many boreal surface waters. The resulting spring flood is an occasion for transient hydrochemical changes that profoundly affect aquatic ecosystems due to changes in $\mathrm{pH}$ and inorganic aluminium concentrations (Laudon et al., 2005; Simonin et al., 1993). The snow melt period is also susceptible to anthropogenic perturbations to water quality that can further impact the biota of surface waters.

The mean annual temperature in Sweden is expected to increase by 3 to $5^{\circ} \mathrm{C}$ during the coming century as a result of the burning of fossil fuels (Kjellström, 2004). This increase is predicted to be more prominent in the northern part of the country and biased towards the winter season. Recent predictions also suggest that these northern ecosystems are among the regions that will be most affected in terms of surface water hydrology and biogeochemistry (Barnett et al., 2005). Another important implication of climate change for northern ecosystems is the expected change in the timing, extent and duration of the snow cover (Venäläinen et al., 2001; Mellander et al., 2007). The snow not only provides a major fraction of the annual water budget, but also plays a fundamental role in regulating the winter biogeochemistry of forest soils (Groffman et al., 2001). How the predicted change in winter conditions will affect the water quality of streams, rivers and lakes in the boreal region is presently not well understood.

Besides contributing the largest component of the ion balance in many boreal surface waters, dissolved organic carbon (DOC) is important for complexing and transporting metals (Rember and Trefry, 2004) as well as a carbon and energy

Published by Copernicus Publications on behalf of the European Geosciences Union. 

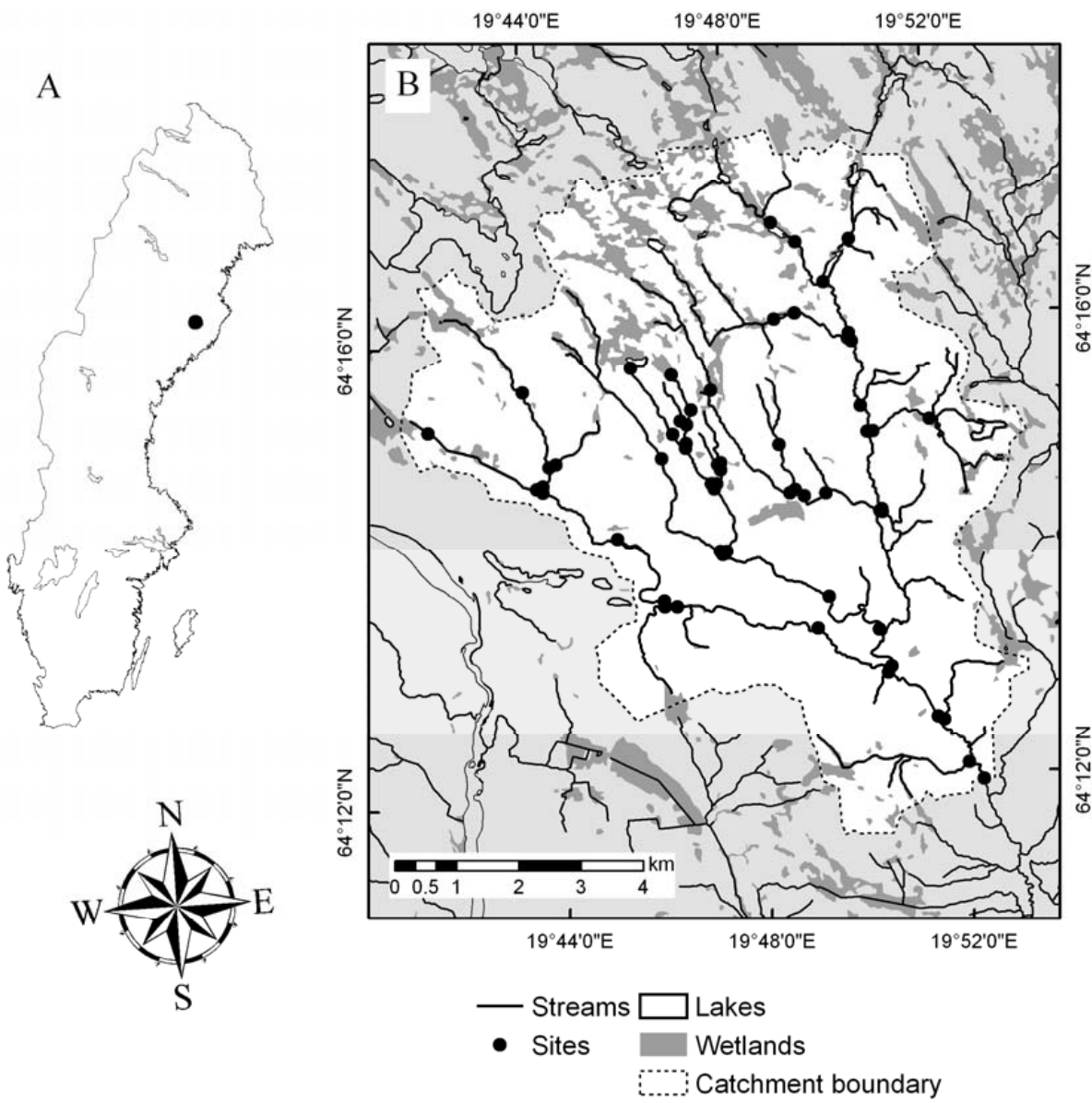

Fig. 1. (A) Location of the Krycklan catchment in Sweden and (B) location of 60 stream sampling sites within the catchment.

source in the aquatic food web (Jansson et al., 2000). In northern Sweden the spring flood DOC concentration is of particular interest because many surface waters experience a $\mathrm{pH}$ decline of one to two $\mathrm{pH}$ units driven primarily by a transient increase in DOC during snow melt (Laudon et al., 2001). A change in the DOC concentration during the spring flood could hence affect the $\mathrm{pH}$ decline occurring in the region and alter the suitability for acid sensitive organisms to dwell in certain streams in the future.

Recent studies in Europe have reported increasing concentrations of DOC in many surface waters. For example, several trend analyses investigations in the UK have shown significantly increasing concentrations the last decades (Evans et al., 2005; Worrall et al., 2004). Similar trends have also been reported from Norway (Hongve et al., 2004) and Finland (Vuorenmaa et al., 2006). Although no single causal mechanism for this wide spread increase in DOC has been identified, several plausible explanations have been proposed, including rising temperatures (Freeman et al., 2001) and long-term variability in hydrological conditions (Tranvik and Jansson, 2002). Recent work by Monteith et al. (2007) demonstrate that this increase in DOC could be caused by a reduction in atmospherically deposited anthropogenic sulphur.

Long and snow rich winters followed by large snowmelt driven hydrological episodes are defining features of northern boreal regions. A change in winter conditions is likely to affect the spring flood in terms of both runoff and solute export. It has been demonstrated that the DOC concentration in streams in northern Sweden is controlled by the soil solution chemistry of the riparian zone in combination with hillslope hydrology (Bishop et al., 2004). Thus, a change in the condition of the near stream zone or in water table level can be expected to change the DOC concentration in adjacent streams during snow melt. Monitoring and modeling studies from other northern regions also suggest that surface water DOC is sensitive to changes in climate, but that the characteristics of the change will vary depending on whether increased temperature or change in precipitation is the dominant response to a warmer climate (Clair et al., 1999; Pastor et al., 2003; Schindler, 2001).

As DOC exudes a strong influence on the $\mathrm{pH}$ of many boreal surface waters, the objective of this study was to quantify how the acidity status of a mesoscale $\left(67 \mathrm{~km}^{2}\right)$ boreal stream 
Table 1. Median (and 5th-95th percentiles in parentheses) catchment characteristics for the stream sites used in the study (N=60 sites) and for all stream cells in the Krycklan catchment $(\mathrm{N}=1654)$.

\begin{tabular}{lcc}
\hline Variable & Sampling sites (N=60) & All stream cells (N=1654) \\
\hline \multicolumn{1}{c}{ SOILS (\%) } & $62.5(45.4-95.9)$ & $62.9(42.9-97.4)$ \\
Till & $13.5(0.0-29.8)$ & $12.6(0.0-32.2)$ \\
Peat & $7.4(0.0-35.9)$ & $1.4(0.0-37.0)$ \\
Sediment (sorted) & $8.7(2.6-27.1)$ & $7.7(0.0-26.6)$ \\
Thin soils & $0.9(0.0-4.6)$ & $0.4(0.0-4.4)$ \\
Exposed rock & & \\
$\quad$ LAND COVER $(\%)$ & $82.3(58.1-96.6)$ & $83.3(61.4-100.0)$ \\
Forest & $12.0(2.5-28.8)$ & $11.1(0.0-30.3)$ \\
Wetland & $2.1(0.0-10.0)$ & $1.1(0.0-14.3)$ \\
Clearcut & $0.6(0.0-3.7)$ & $0.0(0.0-4.1)$ \\
Open or arable & $0.1(0.0-4.1)$ & $0.0(0.0-4.2)$ \\
Lake & & \\
Mean catchment slope $(\%)$ & $9(6-14)$ & $9(6-14)$ \\
Mean catchment altitude $(\mathrm{m})$ & $272(224-295)$ & $277(215-312)$ \\
Site altitude $(\mathrm{m})$ & $198(133-263)$ & $218(146-288)$ \\
Catchment area $\left(\mathrm{km}^{2}\right)$ & $3.3(0.2-41.9)$ & $1.5(0.1-30.5)$ \\
\hline
\end{tabular}

network would be affected by a future change in DOC concentrations. To do this, we modeled the effect of changing DOC concentration (ranging from 30\% decrease to 50\% increase) on $\mathrm{pH}$ at sites distributed throughout the stream network. These data were used to estimate the proportion of the total stream length that would become unsuitable for acid sensitive biota due to changes in DOC concentration, during both base flow conditions and the spring flood.

\section{Study site}

The Krycklan Catchment Study is a multidisciplinary project in the upper $67 \mathrm{~km}^{2}$ of the Krycklan River catchment in northern Sweden (Fig. 1). The catchment includes the Vindeln Experimental Forests $\left(64^{\circ} 14^{\prime} \mathrm{N}, 19^{\circ} 46^{\prime} \mathrm{E}\right)$, where climate data have been monitored at the Svartberget Research Station since 1980. Annual mean air temperature is $1^{\circ} \mathrm{C}$ with $600 \mathrm{~mm}$ annual mean precipitation, of which one-third falls as snow (Ottosson-Löfvenius et al., 2003). Snowcover is present for 171 days on average (1980-1999), and spring snowmelt is the dominant hydrological event of the year, exporting up to $50 \%$ of the annual stream flow during a 3-6 week period in April-May. Both stream water chemistry and discharge have been monitored regularly at one of the small streams, Kallkällsbäcken for the past 25 years (Bishop et al., 1990). Current acid deposition in the catchment is approximately $2 \mathrm{~kg} \mathrm{ha}^{-1} \mathrm{y}^{-1}$ each of $\mathrm{S}-\mathrm{SO}_{4}^{2-}$ and $\mathrm{N}-\mathrm{NO}_{3}^{-}$.

The Krycklan catchment ranges from 130 to 369 meters above sea level. The bedrock consists of gneiss with an up to tens of meters of till overburden. Iron-podzol soils are the most common soil type in the catchment, with organic rich soils in the riparian near stream zones (Bishop et al., 1994). In the lower reaches of the catchment, larger streams have deeply incised channels carving through fine-grained floodplain sediments. Except for patches of sphagnum-dominated peat wetlands, making up $9 \%$ of the entire catchment area (and up to 50\% in some small sub-catchments), the catchment is forested primarily with mature Scots Pine (Pinus sylvestris) in dry upslope areas and Norway Spruce (Picea abies) in wetter, low-lying areas. Deciduous shrubs and trees, primarily birch (Betula spp.) but also alder (Alnus incana) and willow (Salix spp.), are found in the riparian forest along larger streams. Brown trout (Salmo trutta) and Brook trout (Salvelinus fontinalis) are common in many of the streams.

The Krycklan stream network (Fig. 1) from the 1:100 000 scale Swedish topography map (Lantmäteriet, Gävle, Sweden) was used for calculations of stream length. Characteristics of the 60 subcatchments (Table 1) were based on a flow network ( $\mathrm{N}=1654$ cells total) for Krycklan developed within IDRISI v. 14 (Clark Labs, Worcester, MA, USE) using gridded elevation data (DEM) with a grid resolution of $50 \mathrm{~m}$. For soil type characteristics a 1:100 000 digital soil coverage map (Geological Survey of Sweden, Uppsala, Sweden) and for land cover type a 1:12500 scale digital land-cover map was used (Lantmäteriet, Gävle, Sweden). From the soils map, the categories silt, glaciofluvial sediment, sand and gravel were lumped to create a "sorted sediment" soil category. From the land cover map, the categories open and arable were lumped to create an "open or arable" land cover category. 


\section{Field and laboratory measurements}

Stream water sampling consisted of grab samples, with multiple rinses of stream water, collected in acid-washed $250 \mathrm{ml}$ high-density polyethylene bottles. Additional samples for $\mathrm{pCO}_{2}$ analysis were collected in $\mathrm{N}_{2}$-filled $60 \mathrm{~mL}$ glass vials sealed with bromobutyl rubber septa. For each $\mathrm{pCO}_{2}$ sample, a 15-mL aliquot of bubble-free stream water was injected into the glass vial, subsequently acidified to $\mathrm{pH} 2-3$ with 1 drop of $30 \%$ ultrapure $\mathrm{HCl}(0.5 \% \mathrm{v} / \mathrm{v})$ and stored cold until analysis.

Throughout the Krycklan stream network, 60 locations (Fig. 1) were sampled on two separate occasions, during winter base flow and close to peak discharge during spring flood. Samples were collected 5-10 $\mathrm{m}$ above and $25-50 \mathrm{~m}$ below junctions in the stream network. The junction samples were supplemented with samples from sites near the middle of particularly long $(>2 \mathrm{~km})$ stream reaches, and from 15 sites which are part of a long-term monitoring program (Cory et al., 2006; Buffam et al., 2007).

The winter base flow sampling occasion was collected from 17-28 February 2005. Discharge during this period was stable at $0.21-0.22 \mathrm{~mm} \mathrm{day}^{-1}$ at the reference site, typical for winter low-flow discharge with a 25 -year average January-March flow of $0.18 \mathrm{~mm}_{\text {day }}{ }^{-1}$. The spring flood sampling occasion on 22 April 2004 was on the rising limb of the snow melt hydrograph, concurrent with maximum DOC concentration and minimum pH (Buffam et al., 2007). Discharge at the reference site on that day was $3.0 \mathrm{~mm} \mathrm{day}^{-1}$, while peak flood was reached two weeks later on 4 May with $7.1 \mathrm{~mm} \mathrm{day}^{-1}$ of flow during a rain-on-snow event. Peak spring flow in 2004 was within the typical range of $9.7 \pm 3.4 \mathrm{~mm} \mathrm{day}^{-1}$ for the 25 -year mean of the daily peak spring flow at the reference site.

All water samples were kept dark and cool after collection until they were subsampled for chemical analyses. $\mathrm{pH}$ at field condition was measured at laboratory temperature using a Ross 8102 low-conductivity combination electrode (ThermoOrion) in the laboratory immediately after collection. Water samples for DOC analysis were filtered using $0.45 \mu \mathrm{m}$ MCE membrane filters (spring flood sampling) or left unfiltered (winter base flow sampling) and then frozen until analysis. No measurable difference in filtered and unfiltered DOC concentration was detected in this study or in other inter-comparisons in Swedish surface waters (Ivarsson and Jansson, 1994; Köhler et al., 1999). DOC was measured by combustion and analysis as $\mathrm{CO}_{2}$ using a Shimadzu DOCVPCH analyser after acidification and sparging to remove inorganic carbon. Instrument precision based on replicate injections averaged $2 \%$ and was always better than $5 \%$.

Partial pressure of headspace $\mathrm{CO}_{2}$ was analyzed by GC-FID (Perkin Elmer Autosystem Gas chromatograph) equipped with a methanizer operating at $375^{\circ} \mathrm{C}$. Separation was carried out on a Haysep $\mathrm{N}$ column using $\mathrm{He}$ $\left(70 \mathrm{ml} \mathrm{min}^{-1}\right)$ as carrier gas. Duplicate injections of $0.5 \mathrm{~mL}$ were performed for all samples, with additional injections as necessary to attain a coefficient of variation of less than 5\%. Stream water $\mathrm{pCO}_{2}$ was calculated from sample headspace $\mathrm{pCO}_{2}$ using temperature-dependant equations for carbonate equilibria (Gelbrecht et al., 1998) and Henry's Law (Weiss, 1974), together with measured stream water $\mathrm{pH}$ and temperature. For three of the spring flood samples the average $\mathrm{pCO}_{2}$ of the remaining 57 was used as no analyses were available.

Samples for major cation analyses $\left(\mathrm{K}^{+}, \mathrm{Mg}^{2+}, \mathrm{Na}^{+}\right.$, $\left.\mathrm{Ca}^{2+}\right)$ were filtered $(0.45 \mu \mathrm{m}$ MCE membrane filters), preserved with ultrapure $\mathrm{HNO}_{3}^{-}(1 \% \mathrm{v} / \mathrm{v})$ and stored cool until elemental analysis by ICP-OES (inductively-coupled plasma optical emission spectroscopy) on a Varian Vista Ax Pro instrument. Samples for strong acid anions $\left(\mathrm{SO}_{4}^{2-}\right.$ and $\left.\mathrm{Cl}^{-}\right)$ were stored at $6^{\circ} \mathrm{C}$ (2004 samples) or frozen (2005 samples) until analysis, utilizing a Dionex DX-300 or DX-320 ion chromatograph system. The typical precision in anion and cation analyses based on measurements of certified standards was better than $2 \%$. Analysis of $\mathrm{NO}_{3}^{-}$by flow injection analysis on selected samples which had been preserved by filtration and freezing until analysis (one-third of samples) revealed that concentrations were so low as to contribute insignificantly to the charge balance.

\section{Calculations}

Base cation (BC) concentration was calculated as the sum of $\mathrm{K}^{+}, \mathrm{Mg}^{2+}, \mathrm{Na}^{+}$and $\mathrm{Ca}^{2+}$ concentrations expressed as $\mu \mathrm{eq} \mathrm{L}^{-1}$ of charge, with the assumption that these elements were present in their free ionized form. Strong acid anion (SAA) concentration was calculated as the sum of $\mathrm{SO}_{4}^{2-}$ and $\mathrm{Cl}^{-}$expressed as $\mu \mathrm{eq} \mathrm{L}^{-1}$ of charge. Acid neutralizing capacity (ANC) was calculated from the charge balance definition as the difference between strong bases and strong (mineral) acid anions (e.g., Munson and Gherini, 1993), expressed here as molar quantities:

$$
\begin{aligned}
\mathrm{ANC} & =\left[\mathrm{K}^{+}\right]+2\left[\mathrm{Mg}^{2+}\right]+\left[\mathrm{Na}^{+}\right]+2\left[\mathrm{Ca}^{2+}\right]-\left[\mathrm{Cl}^{-}\right] \\
& -2\left[\mathrm{SO}_{4}^{2-}\right]=\mathrm{BC}-\mathrm{SAA}
\end{aligned}
$$

An alternative way to express ANC is as (Eq. 2);

$$
\begin{aligned}
\mathrm{ANC} & =\left[\mathrm{HCO}_{3}^{-}\right]+2\left[\mathrm{CO}_{3}^{2-}\right]+\left[\mathrm{RCOO}^{-}\right]+\left[\mathrm{OH}^{-}\right] \\
& -\left[\mathrm{H}^{+}\right]-\mathrm{n}\left[\mathrm{Al}^{\mathrm{n}+}\right]
\end{aligned}
$$

where $\mathrm{HCO}_{3}^{-}$is calculated from $\mathrm{pCO}_{2}$ using Henry's law and the carbonate equilibria equations. $\mathrm{CO}_{3}^{2-}$ was excluded from the calculation, as $\mathrm{pH}$ always was below 7.0 and hence $\mathrm{CO}_{3}^{2-}$ does not affect the $\mathrm{pH}$ modeling. $\mathrm{RCOO}^{-}$denotes dissociated organic acid anions, including both the strong and weak acid anions, and is calculated from DOC and $\mathrm{pH}$ using an organic acid model presented by Hruska et al. (2003). Al ${ }^{n+}$ denotes positively charged inorganic monomeric $\mathrm{Al}$-species. As previous studies have shown that the inclusion of $\mathrm{Al}^{n+}$ 
does not significantly improve the agreement between measured and model-predicted $\mathrm{pH}$ over the range of $\mathrm{Al}$ concentrations, DOC and $\mathrm{pH}$ found in these stream water samples (Köhler et al., 2000), $\mathrm{Al}^{n+}$ was also excluded from the calculations. $\mathrm{H}^{+}$can hence be calculated as (Eq. 3):

$\left[\mathrm{H}^{+}\right]=\left[\mathrm{HCO}_{3}^{-}\right]+\left[\mathrm{RCOO}^{-}\right]+\left[\mathrm{OH}^{-}\right]-\mathrm{BC}+\mathrm{SAA}$

Because $\mathrm{HCO}_{3}^{-}, \mathrm{RCOO}^{-}$and $\mathrm{OH}^{-}$are $\mathrm{pH}$ dependent Eq. (3) was solved iteratively.

The effect of a change in DOC on stream water $\mathrm{pH}$ was calculated using Eqs. (4-7), where the first step was to model the field proton concentration $\left(\mathrm{H}_{\text {modeled-field }}^{+}\right)$using measured $\mathrm{pCO}_{2}$, DOC, BC and SAA concentrations (Eq. 4). The effect of a change in DOC concentration on the $\mathrm{H}^{+}\left(\mathrm{H}_{\Delta \mathrm{DOC}}^{+}\right)$ was then calculated, by adjusting DOC and hence $\mathrm{RCOO}^{-}$ accordingly, then re-establishing charge balance while maintaining the measured concentrations of $\mathrm{pCO}_{2}, \mathrm{BC}$, and SAA (Eq. 5). After calculating $\Delta \mathrm{H}^{+}$as the difference between modeled field $\mathrm{H}^{+}$and the new $\mathrm{H}^{+}\left(\mathrm{H}_{\Delta \mathrm{DOC}}^{+}\right)$after DOC adjustment (Eq. 6) the final $\mathrm{pH}$ value $\left(\mathrm{pH}_{\text {new }}\right)$ used in the stream sensitivity analyses was calculated using Eq. (7).

$\mathrm{H}_{\text {modeled-field }}^{+}=\left[\mathrm{HCO}_{3}^{-}\right]+\left[\mathrm{RCOO}^{-}\right]+\left[\mathrm{OH}^{-}\right]-\mathrm{BC}+\mathrm{SAA}$

$\mathrm{H}_{\triangle \mathrm{DOC}}^{+}=\left[\mathrm{HCO}_{3}^{-}\right]_{\triangle \mathrm{DOC}}+\left[\mathrm{RCOO}^{-}\right]_{\triangle \mathrm{DOC}}$

$+\left[\mathrm{OH}^{-}\right]_{\triangle \mathrm{DOC}}-\mathrm{BC}+\mathrm{SAA}$

$\Delta \mathrm{H}^{+}=\mathrm{H}_{\Delta \mathrm{DOC}}^{+}-\mathrm{H}_{\text {modeled-field }}^{+}$

$\mathrm{pH}_{\text {new }}=-\log \left(\mathrm{H}_{\text {measured }}^{+}+\Delta \mathrm{H}^{+}\right)$

This procedure was repeated for all 60 stream sites using both winter base flow and spring flood chemistry as the starting point for changes in DOC ranging from $-30 \%$ to $+50 \%$. The reason for calculating $\Delta \mathrm{H}^{+}$, which is than added to the measured $\mathrm{H}_{\text {modeled-field }}^{+}$concentration instead of using modeled $\mathrm{pH}$ with a DOC change directly, was to minimize the uncertainty in the organic acid modeling. By using the suite of equations (Eqs. 4-7) much of the uncertainty cancels out.

\subsection{Stream length}

The chemistry of each site was associated with its respective stream segment, both for purposes of illustrative mapping and to express the chemical status of the stream network in terms of proportion of stream length, rather than as proportion of sites. The length of each stream segment was determined by extending from a given site to the halfway point (distance measured along stream) between adjacent sampling sites, both upstream and downstream. In the case of headwater sites, stream segments were extended halfway to the furthest upstream extent of the perennial stream, as indicated on the 1:100000 scale map. Stream segments were not extended beyond major junctions. The length of the resulting stream segments varied between $68 \mathrm{~m}$ and $2874 \mathrm{~m}$, with a mean length of $941 \mathrm{~m}$. From this calculation, we estimated that our 60 sampling sites represented a total of $56 \mathrm{~km}$ of stream length, out of a total of $96 \mathrm{~km}$ in the whole network. For the remainder of the study, stream lengths are expressed as a percentage of total measured stream length, i.e., $56 \mathrm{~km}$.

\section{2 $\mathrm{pH}$ range of interest for acid sensitive species}

Toxicity of water quality to fish and aquatic invertebrate populations in acidic systems has been linked to both low $\mathrm{pH}$ and elevated inorganic aluminium $\left(\mathrm{Al}_{i}\right)$. Al toxicity (e.g., Gensemer and Playle, 1999) is frequently the primary cause of acid impacts on biota in low DOC aquatic systems. In aquatic systems such as those covering much of northern Sweden, high DOC concentrations bind aluminium reducing its toxic effects (Laudon et al., 2005; Simonin et al., 1993; Witters et al., 1990). For example, Atlantic salmon are limited by $\mathrm{pH}$ with no clear physiological or toxicological response to $\mathrm{Al}$ concentrations in high DOC streams of Nova Scotia, Canada (Lacroix, 1989). In a recent study conducted by the Swedish EPA reviewing all available national lake and stream water quality and biological data, $\mathrm{pH}$ rather than $\mathrm{Al}_{i}$ was recommended as preferred acidity index. This was because $\mathrm{pH}$ was found to correlate as well as or better than $\mathrm{Al}_{i}$ to presence/absence of acid-sensitive fish species and stages (Holmgren and Buffam, 2005), and better than $\mathrm{Al}_{i}$ to the presence/absence of acid-sensitive invertebrate species (Fölster et al., 2007). Furthermore these studies suggested that the most critical $\mathrm{pH}$ interval for many acid sensitive species generally is between $\mathrm{pH} 5.5$ and 5.0. Based on these results we used two thresholds in this study; $\mathrm{pH} 5.5$ and $\mathrm{pH} 5.0$ to assess the potential change in biological status due to changes in DOC concentration during the spring flood.

\section{Results}

The sampling conducted during both winter and spring represents a stream length of $56 \mathrm{~km}$ out of the total $96 \mathrm{~km}$ of stream length in the Krycklan catchment. The gaps in coverage were primarily due to under-sampling of the smallest first order tributaries. This gave a distribution of sample sites with a median of $3.3 \mathrm{~km}^{2}$ as compared to $1.5 \mathrm{~km}^{2}$ for the entire network of potential sampling sites (Table 1). This under-representation of the smallest streams can mainly be attributed to inaccessibility or frozen stream channels during winter sampling. Due to this tendency to under-represent the headwaters there was also an over-representation of areas with sorted sediments and open or arable land, which occurred mostly along larger streams in the lower reaches of the catchment. Otherwise, the distributions of subcatchment characteristics (soil, land-cover parameters) for the 60 sites replicated well the distribution of potential sampling points from the entire stream network (Table 1). This is of importance because much of the inter-stream variation in stream 


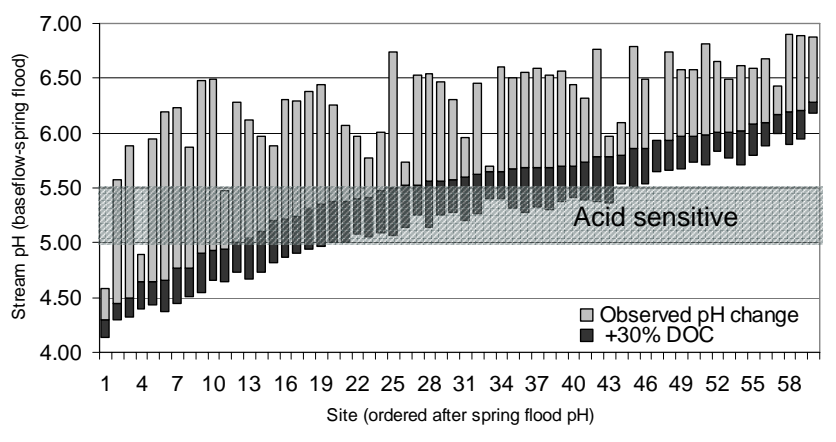

Fig. 2. The decline in $\mathrm{pH}$ at 60 stream sites, measured from base flow to spring flood (gray) and with the further modeled decline due to $30 \%$ increase in spring flood DOC (black). The streams are sorted by spring flood $\mathrm{pH}$.

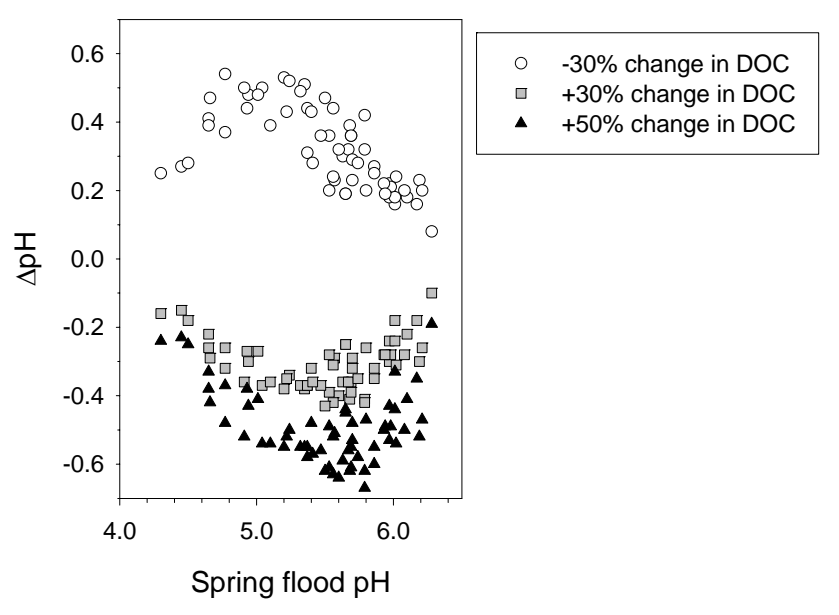

Fig. 3. The effect of a change in DOC on spring flood $\mathrm{pH}$ at 60 stream sites.

water chemistry is related to spatial patterns in the terrestrial landscape, in particular the distribution of peat wetlands (Buffam et al., 2007; Ågren al., 2007).

The average contemporary DOC concentration at base flow was $10.6 \mathrm{mg} \mathrm{L}^{-1}$ (Table 2) with a standard deviation $(\sigma)$ of $6.3 \mathrm{mg} \mathrm{L}^{-1}$, and varied largely depending on the distribution of wetlands (Buffam et al., 2007). During spring flood DOC concentration generally increased to an average of $17.8 \mathrm{mg} \mathrm{L}^{-1}\left(\sigma 3.7 \mathrm{mg} \mathrm{L}^{-1}\right)$. Average ANC at base flow was $225 \mu \mathrm{eq} \mathrm{L}^{-1}\left(\sigma 124 \mu \mathrm{eq} \mathrm{L}^{-1}\right)$, which generally diluted during spring flood to $123 \mu \mathrm{eq} \mathrm{L}^{-1}\left(\sigma 33 \mu \mathrm{eq} \mathrm{L} \mathrm{L}^{-1}\right)$. Average $\mathrm{pH}$ during base flow and spring flood was $6.28(\sigma 0.45 \mathrm{pH}$ units) and $5.49(\sigma 0.49 \mathrm{pH}$ units), respectively. During base flow average $\mathrm{pCO}_{2}$ was $2804 \mathrm{ppm}(\sigma 2959 \mathrm{ppm})$ whereas average $\mathrm{pCO}_{2}$ during spring flood was $3557 \mathrm{ppm}(\sigma 806 \mathrm{ppm})$. The $\mathrm{pCO}_{2}$ during spring flood averaged almost ten times overpressure compared to atmospheric $\mathrm{CO}_{2}$.

The $\mathrm{pH}$ model succeeded well in replicating field $\mathrm{pH}$ values from measured concentrations of $\mathrm{pCO}_{2}, \mathrm{BC}, \mathrm{SAA}$
Table 2. Mean chemistry (standard deviation in parentheses) for the 60 stream sites used in the study during winter base flow and spring flood. $\mathrm{DOC}=$ dissolved organic carbon; $\mathrm{RCOO}^{-}=$dissociated organic acids (modeled, including both strong and weak component); $\mathrm{BC}=$ base cations; $\mathrm{SAA}=$ strong acid anions; $\mathrm{ANC}=$ acid neutralizing capacity (BC-SAA).

\begin{tabular}{lccc}
\hline Variable & & Winter Base Flow & Spring Flood \\
\hline $\mathrm{pH}$ & & $6.28(0.45)$ & $5.49(0.49)$ \\
$\mathrm{DOC}$ & $\left(\mathrm{mg} \mathrm{L}^{-1}\right)$ & $10.6(6.3)$ & $17.8(3.7)$ \\
$\mathrm{RCOO}^{-}$ & $\left(\mu \mathrm{eq} \mathrm{L}^{-1}\right)$ & $83(41)$ & $118(15)$ \\
$\mathrm{BC}$ & $\left.(\mu \mathrm{eq} \mathrm{L})^{-1}\right)$ & $373(227)$ & $229(54)$ \\
$\mathrm{SAA}$ & $\left.(\mu \mathrm{eq} \mathrm{L})^{-1}\right)$ & $148(117)$ & $106(33)$ \\
$\mathrm{ANC}$ & $\left.(\mu \mathrm{eq} \mathrm{L})^{-1}\right)$ & $225(124)$ & $123(33)$ \\
$\mathrm{Ca}^{2+}$ & $\left.(\mu \mathrm{eq} \mathrm{L})^{-1}\right)$ & $163(127)$ & $103(31)$ \\
$\mathrm{K}^{+}$ & $\left.(\mu \mathrm{eq} \mathrm{L})^{-1}\right)$ & $20(15)$ & $20(11)$ \\
$\mathrm{Mg}^{2+}$ & $\left.(\mu \mathrm{eq} \mathrm{L})^{-1}\right)$ & $90(58)$ & $56(12)$ \\
$\mathrm{Na}^{+}$ & $\left.(\mu \mathrm{eq} \mathrm{L})^{-1}\right)$ & $100(31)$ & $49(12)$ \\
$\mathrm{Cl}^{-}$ & $\left.(\mu \mathrm{eq} \mathrm{L})^{-1}\right)$ & $33(11)$ & $25(6)$ \\
$\mathrm{SO}_{4}^{2-}$ & $\left.(\mu \mathrm{eq} \mathrm{L})^{-1}\right)$ & $115(110)$ & $81(31)$ \\
$\mathrm{HCO}_{3}^{-}$ & $\left.(\mu \mathrm{eq} \mathrm{L})^{-1}\right)$ & $97(65)$ & $31(27)$ \\
$\mathrm{pCO}_{2}$ & $\mathrm{ppm}$ & $2804(2959)$ & $3557(806)$ \\
\hline
\end{tabular}

and DOC. During spring flood the root mean square error (RMSE) between measured and modeled $\mathrm{pH}$ was $0.15 \mathrm{pH}$ units. At base flow the RMSE was $0.25 \mathrm{pH}$ units.

The modeled response in stream water $\mathrm{pH}$ due to changes in DOC concentration varied between base flow and spring flood. With a $30 \%$ increase in DOC concentration the average modeled $\mathrm{pH}$ decline during base flow was only $0.11 \mathrm{pH}$ units. The modeled drop during spring flood was much larger, averaging $0.31 \mathrm{pH}$ units (Fig. 2). During spring flood the largest $\mathrm{pH}$ effect was observed for samples with a pH between 5 and 6, which dropped on average $0.34 \mathrm{pH}$ units with a $30 \%$ increase in DOC (Fig. 3). Streams with a spring flood $\mathrm{pH}$ below 5.0 had an average $\mathrm{pH}$ decline of $0.25 \mathrm{pH}$ units, whereas streams with a spring flood $\mathrm{pH}$ above $6.0 \mathrm{had}$ an average $\mathrm{pH}$ decline of $0.22 \mathrm{pH}$ units.

With the present DOC concentration, $92 \%$ of the measured stream length experienced a $\mathrm{pH}$ above 5.5 during base flow conditions while the stream length with a $\mathrm{pH}$ above 5.0 was 93\% (Fig. 4a). During spring flood the stream length with $\mathrm{pH}$ above 5.5 and 5.0 was $63 \%$ and $82 \%$ respectively with current DOC concentrations. With an increase in DOC concentration by $30 \%$ from present conditions (to an average of $13.8 \mathrm{mg} \mathrm{L}^{-1}\left(\sigma 8.1 \mathrm{mg} \mathrm{L}^{-1}\right)$ at base flow and $24.8 \mathrm{mg} \mathrm{L}^{-1}$ $\left(\sigma 5.1 \mathrm{mg} \mathrm{L}^{-1}\right)$ at spring flood) the stream length with $\mathrm{pH}$ above 5.5 and 5.0 would decrease to $86 \%$ and $92 \%$ during base flow and to $35 \%$ and $73 \%$ during spring flood (Fig. 4b).

Other DOC change scenarios also showed substantial impacts on the proportion of suitable stream length (Fig. 5). If the DOC concentration in all measured streams 

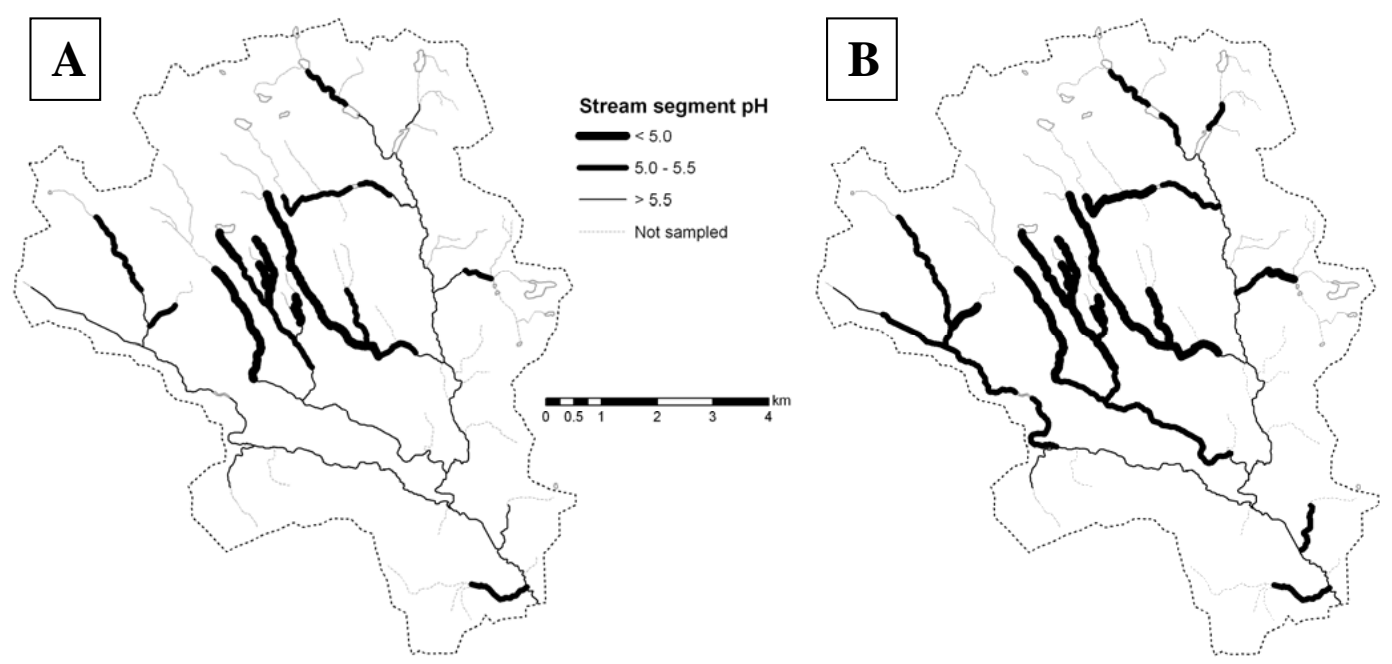

Fig. 4. The proportion of stream length affected by low $\mathrm{pH}$ at spring flood (A) during present conditions and (B) following a $30 \%$ increase in DOC.

were decreased by $30 \%$ (to an average of $7.4 \mathrm{mg} \mathrm{L}^{-1}$ $\left(\sigma 4.4 \mathrm{mg} \mathrm{L}^{-1}\right)$ at base flow and $12.4 \mathrm{mg} \mathrm{L}^{-1}\left(\sigma 2.4 \mathrm{mg} \mathrm{L}^{-1}\right)$ at spring flood) the length of streams above $\mathrm{pH} 5.5$ and 5.0, respectively would increase slightly to $93 \%$ and $95 \%$ during base flow and to $81 \%$ and $92 \%$ during spring flood. At the other extreme, if the DOC concentration increased by $50 \%$ from present conditions (to an average of $15.9 \mathrm{mg} \mathrm{L}^{-1}$ $\left(\sigma 9.4 \mathrm{mg} \mathrm{L}^{-1}\right)$ at base flow and $26.7 \mathrm{mg} \mathrm{L}^{-1}\left(\sigma 5.5 \mathrm{mg} \mathrm{L}^{-1}\right)$ at spring flood) the stream length in the Krycklan catchment with a winter base flow $\mathrm{pH}$ above 5.5 and 5.0 would be $80 \%$ and $92 \%$, respectively (Fig. 5). A $50 \%$ increase in DOC concentration during spring flood would result in a stream length with $\mathrm{pH}$ above 5.5 of only $15 \%$, while $57 \%$ would have a spring flood $\mathrm{pH}$ above 5.0.

\section{Discussion}

The proportion of stream length sensitive to changes in DOC was seasonally dependent. The two sampling occasions used in this study were selected to represent the extreme conditions experienced in Swedish boreal streams, both in terms of discharge and in acid-base chemistry. Late winter base flow in the region is generally well buffered with high ANC and relatively low DOC concentrations (Bishop et al., 2000; Laudon and Bishop, 2002) and $\mathrm{pH}$ is therefore not strongly affected by moderate changes in DOC. The amount of stream length that was depressed into or below the acid sensitive range $(\mathrm{pH}$ 5.0-5.5) was therefore low independent of the change in DOC in our scenarios. In contrast, during the snow melt period streams in the region experience a large natural increase in DOC concentration which in combination with a dilution of ANC generally results in the minimum annual pH levels (Laudon et al., 2000; Buffam et al., 2007). Based on our modeling results, an additional change in DOC con- centration during this period would result in large changes in spring flood $\mathrm{pH}$ and hence in the stream length impacted by low pH (Figs. 4b and 5).

The magnitude of the change in $\mathrm{pH}$ during the spring flood was mainly related to the field $\mathrm{pH}$ value with no correlation to measured DOC or ANC in the 60 streams. In general the largest $\mathrm{pH}$ change was found for streams with spring flood $\mathrm{pH}$ between 5 and 6 (Fig. 3), with declining effects both above $\mathrm{pH} 6$ and below pH 5, which can be attributed to low buffering capacity of high DOC surface waters in the $\mathrm{pH} 5$ to 6 range (Köhler et al., 1999). This means that streams that already have a $\mathrm{pH}$ near ecological $\mathrm{pH}$ thresholds also are the systems that will likely experience the largest change in $\mathrm{pH}$ if the DOC concentration is affected in the future.

The prediction of how a DOC change will affect the stream length available to acid sensitive fish and invertebrate species was based on two simple thresholds in $\mathrm{pH}$ : $\mathrm{pH} 5.5$ and $\mathrm{pH}$ 5.0. Although these toxicity thresholds were based on a recent study conducted by the Swedish EPA where a substantial body of national water quality and biological data were reviewed (Holmgren and Buffam, 2005; Fölster et al., 2007), this is admittedly an over-simplification of the ecological response to episodic $\mathrm{pH}$ changes. Sensitivity to acidity not only varies between species but also depends on the different development stages of the organisms (McCormick and Leino, 1999; Sayer et al., 1993). Another consequence of a change in climate is therefore on the timing of snowmelt that could result in changes in synchronization between high runoff (and hence low $\mathrm{pH}$ ) and vulnerable life-stages of fish. As the winter/spring period is an important bottleneck for many stream-dwelling fish-species, with decreasing amount of prey and increased predation (Elliott, 1994), any major change in the environmental conditions during these periods could contribute to first-year recruitment failure in northern 

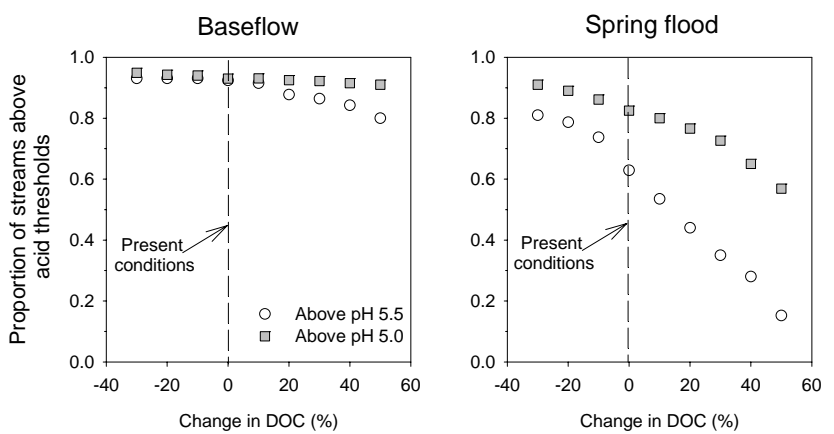

Fig. 5. The effects on stream length experiencing low $\mathrm{pH}$ at both base flow (left) and spring flood (right) using the entire range of changes in DOC (from $-30 \%$ to $+50 \%$ ).

waters (McCormick and Leino, 1999). However, the purpose of this study was not to develop new ecological thresholds, but to demonstrate the potential impact of changes in DOC concentration using a simple approach. It is hoped that future studies will expand and improve the complexity of the biological thresholds that can be used for this type of analysis.

A 50\% increase in DOC concentration used as an upper limit in this study is within what has been recorded in surface water monitoring in Europe during the last decades. In a recent study of 22 UK upland surface waters the DOC concentration increased on average by $91 \%$ the last 15 years (Evans et al., 2005). Similar results have been reported in another large study in the UK involving 198 sites, where $77 \%$ of the sites increased in concentration with an average increase of $0.17 \mathrm{mg} \mathrm{DOC} \mathrm{L}^{-1}$ year $^{-1}$ measured over an 8 to 42 year time span (Worrall et al., 2004). In Finland a corresponding increase in DOC for 13 lakes was found to average $0.11 \mathrm{mg} \mathrm{DOC} \mathrm{L}^{-1} \mathrm{yr}^{-1}$, where the largest increase of $0.22 \mathrm{mg} \mathrm{DOC} \mathrm{L} \mathrm{Lr}^{-1} \mathrm{yr}^{-1}$ was found in the lake with the highest initial DOC concentration (Vuorenmaa et al., 2006).

The concentration of organic carbon in surface waters in high latitude regions is expected to be particularly susceptible to changes in climate (Finlay et al., 2006). At the hillslope scale the concentration of DOC in streams is controlled by soil solution chemistry in the near stream zone in combination with hillslope hydrology (Bishop et al., 1994). As the soil DOC increases exponentially towards the soil surface, increased runoff resulting in more superficial flow pathways in the soil will therefore likely increase the concentration of DOC during the spring flood. A more prolonged snow melt period, which is another plausible consequence of warmer winters, may have the opposite effect and decrease the runoff peak and hence lower future DOC concentrations during spring flood.

As the stream DOC concentration is strongly regulated by the riparian zone (Bishop et al., 2004), changes in physical conditions of the near stream soil would also likely alter the available DOC that can be exported to the adjacent stream during the spring flood. One such effect that is driven by changes in the winter climate is an alteration of the spatial and temporal distribution of soil frost (Mellander et al., 2005). A later development of the snow pack, which is a likely effect of a warmer climate, may result in an increased number of freeze-thaw events or even colder soils in some situations because of longer periods during winter when the soil is not insulated by snow (Stieglitz et al., 2003). How a change in the soil frost distribution will affect the DOC concentrations during the spring flood is however presently not well understood.

One important assumption made in this analysis is that the acid-base character of DOC is constant over time and space. This has been confirmed by several studies in the region (Köhler et al., 1999; Hruska et al., 2001). The reasonable reproduction of field $\mathrm{pH}$ from measurements of ANC, $\mathrm{pCO}_{2}$ and DOC in this study, with a RMSE of $0.25 \mathrm{pH}$ units during base flow and $0.15 \mathrm{pH}$ units during spring flood further confirms a relatively consistent DOC character in the region. Furthermore, the potential for biased results due to systematic errors in the acid-base character was minimized by calculating the effect on $\mathrm{pH}$ as the difference in $\mathrm{H}^{+}$(Eq. 6) between modeled field $\mathrm{H}^{+}$and $\mathrm{H}^{+}$after DOC adjustment, which should cancel out major systematic errors.

Another important assumption made in this study is that a change in DOC could occur with no accompanying change in ANC. From a theoretical perspective, it is likely that an increase in DOC, and therefore in the concentration of $\mathrm{RCOO}^{-}$, would result in a proportional increase in $\mathrm{BC}$ and hence in ANC (Kahl et al., 1992). If the change in DOC concentration is caused by an alteration in hydrology of the riparian zone, other spring flood studies in the area suggest that this co-transport should be minimal. Laudon et al. (2001) compared the dilution of BC with the change in the more conservative hydrological tracer silica $(\mathrm{Si})$ in a number of streams in northern Sweden, including several of the streams in this study. In a majority of cases a similar or even larger decline during the spring flood was observed in BC compared to $\mathrm{Si}$, despite an up $200 \%$ increase in DOC. Bishop et al. (2004) have also provided a physical explanation to the lack of proportionality between DOC and BC change; whereas the DOC concentration in the near stream zone increases exponentially towards the soil surface, the $\mathrm{BC}$ concentration declines in the same direction. An increased ground water table will hence activate flow paths of higher DOC but lower BC concentrations during episodes, which could further exacerbate the negative influence on $\mathrm{pH}$. A negative correlation between DOC and BC in this study during both base flow $(\mathrm{p}=0.001)$ and spring flood $(\mathrm{p}=0.005)$ also suggests that despite a theoretical basis for a co-transport large variability in DOC can occur during the spring flood without a corresponding change in ANC.

If, on the other hand, an increase in DOC is caused by a declining acid deposition as suggested by Monteith et al. (2007), a recovery of ANC could be expected, which 
would remediate the negative influence on $\mathrm{pH}$. Previous analyses of spring flood episodes in northern Sweden have however demonstrated that the pulse of acidity generating $\mathrm{pH}$ decline over two $\mathrm{pH}$ units in many streams, is now derived primarily from an increase in naturally occurring organic acids in conjunction with the dilution of ANC (Bishop et al., 2000; Laudon et al., 2001). As anthropogenic deposition at present only contributes between 0.1 and $0.3 \mathrm{pH}$ units to the spring flood $\mathrm{pH}$ decline, little further recovery can be expected in the future (Laudon and Bishop, 2002; Laudon and Hemond, 2002). While the acid-emissions related acidification pressure has been declining, climate change is expected to be an increasing threat to the region's aquatic resources.

A third uncertainty in predicting sensitivity to future changes is how $\mathrm{pCO}_{2}$ would be affected. The $\mathrm{pCO}_{2}$ has a large influence on $\mathrm{pH}$ during both base flow and spring flood. For example if the $\mathrm{pCO}_{2}$ were in equilibrium with the atmosphere, instead of the almost 10 times mean over-pressure measured, the average $\mathrm{pH}$ during the spring flood would on average for the 60 stream sites be $0.4 \mathrm{pH}$ units higher. Because of a significant positive correlation $(\mathrm{p}=0.004)$ between $\mathrm{DOC}$ and $\mathrm{pCO}_{2}$ suggesting similar source areas, an increase in DOC could occur together with increased $\mathrm{pCO}_{2}$ during the spring flood. This would result in a further depression of $\mathrm{pH}$ in the range sensitive to buffering by $\mathrm{CO}_{2}(\mathrm{pH}>5)$.

\section{Conclusion}

In this work we have investigated the potential implications of changes in the DOC concentration on stream water biota using a mesoscale boreal stream network in northern Sweden. The results suggest that in low buffered systems, especially during the spring flood, even a marginal change in the DOC concentration can impact acid sensitive biota in a large portion of the aquatic landscape.

The premise of the modeling exercise in this study was to demonstrate the impact of changes in DOC concentration alone on $\mathrm{pH}$. As variation in DOC concentration is not expected to occur in isolation but instead to be accompanied by variation in other solutes, the causal mechanism behind changes in DOC has considerable implications for the likely impact on $\mathrm{pH}$. If changes in DOC are caused by shifting water tables resulting from changes in temperature or the temporal distribution of precipitation and temperature, for instance, resulting changes in $\mathrm{pH}$ are likely to be even more extreme than those predicted in this study. That is because soil flow pathways which favor high DOC concentrations tend to be near-surface and thus low in $\mathrm{BC}$ relative to deeper flow pathways. Increases in DOC are thus likely to be accompanied by decreases in $\mathrm{BC}$, further exacerbating changes in $\mathrm{pH}$, and vice versa for decreases in DOC. On the other hand, if current or future changes in DOC are the result of recovery from soil acidification, then the increasing organic acid concentrations will be accompanied by decreases in strong acid anions (e.g. $\mathrm{SO}_{4}^{2-}$ ) and/or increases in $\mathrm{BC}$. This will result in little or no change in $\mathrm{pH}$ for a given change in DOC. It is plausible that both mechanisms could be operating in the same systems simultaneously, lending uncertainty to simple prediction of the impact of changing DOC on $\mathrm{pH}$. Regardless, in high-DOC systems DOC plays an important role in controlling $\mathrm{pH}$, and thus consideration of this factor is important especially given the current trends in DOC concentration across many regions.

Edited by: P. Dillon and R. F. Wright

\section{References}

Ågren, A., Buffam, I., Jansson, M., and Laudon, H.: Importance of seasonality and small streams for the landscape regulation of DOC export, J. Geophys. Res., 112, G03003, doi:10.1029/2006 JG000381, 2007.

Barnett, T. P., Adam, J. C., and Lettenmaier, D. P.: Potential impacts of a warming climate on water availability in snow-dominated regions, Nature, 438, 303-309, 2005.

Bishop, K., Pettersson, C., Allard, B., and Lee, Y. H.: Identification of the Riparian Sources of Aquatic Dissolved Organic-Carbon, Environ. Int., 20, 11-19, 1994.

Bishop, K., Seibert, J., Köhler, S., and Laudon, H.: Resolving the Double Paradox of rapidly mobilized old water with highly variable responses in runoff chemistry, Hydrol. Process., 18, 185189, 2004.

Bishop, K. H., Grip, H., and O'Neill, A.: The origin of acid runoff in a hillslope during storm events, J. Hydrol., 116, 35-61, 1990.

Bishop, K. H., Laudon, H., and Köhler, S.: Separating the natural and anthropogenic components of spring flood $\mathrm{pH}$ decline: A method for areas that are not chronically acidified, Water Resour. Res., 30, 1873-1889, 2000.

Buffam, I., Laudon, H., Temnerud, J., Mörth, C. M., and Bishop, K.: Landscape-scale variability of acidity and dissolved organic carbon during spring flood in a boreal stream network, J. Geophys. Res., 112, G01022, doi:10.1029/2006JG000218, 2007.

Clair, T. A., Ehrman, J. M., and Higuchi, K.: Changes in freshwater carbon exports from Canadian terrestrial basins to lakes and estuaries under a $2 \mathrm{XCO}_{2}$ atmospheric scenario, Global Biogeochem. Cy., 13, 1091-1097, 1999.

Cory, N., Buffam, I., Laudon, H., Kohler, S., and Bishop, K.: Landscape control of stream water aluminum in a boreal catchment during spring flood, Environ. Sci. Technol., 40, 3494-3500, 2006.

Elliott, J. M.: Quantitative Ecology and the Brown Trout, Oxford University Press, Walton Street, Oxford OX2 6DP, p. 286, 1994.

Evans, C. D., Monteith, D. T., and Cooper, D. M.: Long-term increases in surface water dissolved organic carbon: Observations, possible causes and environmental impacts, Environ. Pollut., 137, 55-71, 2005.

Finlay, J., Neff, J., Zimov, S., Davydova, A., and Davydov, S.: Snowmelt dominance of dissolved organic carbon in high-latitude watersheds: Implications for characterization and flux of river DOC, Geophys. Res. Lett., 33, L10401, doi:10.1029/2006GL025754, 2006.

Fölster, J., Andrén, C., Bishop, K., Buffam, I., Cory, N., Goedkoop, W., Holmgren, K., Johnson, R., Laudon, H., and Wilander, A.: New Environmental Quality Criteria for acidification in lakes in Sweden - an application of studies on the relationship 
between biota and water chemistry, Water Air Soil Poll., 7, 331338, 2007.

Freeman, C., Evans, C. D., Monteith, D. T., Reynolds, B., and Fenner, N.: Export of organic carbon from peat soils, Nature, 412, 785-785, 2001.

Gelbrecht, J., Fait, M., Dittrich, M., and Steinberg, C.: Use of GC and equilibrium calculations of $\mathrm{CO} 2$ saturation index to indicate whether freshwater bodies in north-eastern Germany are net sources or sinks for atmospheric CO2, Fresen, J. Anal. Chem., 361, 47-53, 1998.

Gensemer, R. W. and Playle, R. C.: The bioavailability and toxicity of aluminum in aquatic environments, Crit. Rev. Env. Sci. Tech., 29, 315-450, 1999.

Groffman, P. M., Driscoll, C. T., Fahey, T. J., Hardy, J. P., Fitzhugh, R. D., and Tierney, G. L.: Colder soils in a warmer world: A snow manipulation study in a northern hardwood forest ecosystem, Biogeochemistry, 56, 135-150, 2001.

Holmgren, K. and Buffam, I.: Critical values of different acidity indices - as shown by fish communities in Swedish lakes, Verh. Internat. Verein. Limnol., 29, 654-660, 2005.

Hongve, D., Riise, G., and Kristiansen, J. F.: Increased colour and organic acid concentrations in Norwegian forest lakes and drinking water - a result of increased precipitation?, Aquat. Sci., 66, 231-238, 2004.

Hruska, J., Kohler, S., Laudon, H., and Bishop, K.: Is a universal model of organic acidity possible: Comparison of the acid/base properties of dissolved organic carbon in the boreal and temperate zones, Environ. Sci. Technol., 37, 1726-1730, 2003.

Hruska, J., Laudon, H., Johnson, C. E., Kohler, S., and Bishop, K.: Acid/base character of organic acids in a boreal stream during snowmelt, Water Resour. Res., 37, 1043-1056, 2001.

Ivarsson, H. and Jansson, M.: Temporal variations in the concentration and character of dissolved Organic-matter in a highly colored stream in the coastal zone of northern Sweden, Arch. Hydrobiol., 132, 45-55, 1994.

Jansson, M., Bergstrom, A. K., Blomqvist, P., and Drakare, S.: Allochthonous organic carbon and phytoplankton/bacterioplankton production relationships in lakes, Ecology, 81, 3250-3255, 2000.

Kahl, J. S., Norton, S. A., Haines, T. A., Rochette, E. A., Heath, R. H., and Nodvin, S. C.: Mechanisms of episodic acidification in low-order streams in Maine, USA, Environ. Pollut., 78, 37-44, 1992

Kjellström, E.: Recent and future signatures of climate change in Europe, Ambio, 33, 193-198, 2004.

Köhler, S., Hruska, J., and Bishop, K.: Influence of organic acid site density on $\mathrm{pH}$ modeling of Swedish lakes, Can. J. Fish. Aquat. Sci., 56, 1461-1470, 1999.

Köhler, S., Laudon, H., Wilander, A., and Bishop, K.: Estimating organic acid dissociation in natural surface waters using total alkalinity and TOC, Water Res., 34, 1425-1434, 2000.

Lacroix, G. L.: Ecological and Physiological Responses of Atlantic Salmon in Acidic Organic Rivers of Nova Scotia, Canada, Water Air Soil Poll., 46, 375-386, 1989.

Laudon, H. and Bishop, K. H.: The rapid and extensive recovery from episodic acidification in northern Sweden due to declines in SO42-deposition, Geophys. Res. Lett., 29, 1594, doi:10.1029/2001GL014211, 2002.

Laudon, H. and Hemond, H. F.: Recovery of streams from episodic acidification in northern Sweden, Environ. Sci. Technol., 36,
921-928, 2002.

Laudon, H., Poleo, A. B. S., Vollestad, L. A., and Bishop, K.: Survival of brown trout during spring flood in DOC-rich streams in northern Sweden: the effect of present acid deposition and modeled pre-industrial water quality, Environ. Pollut., 135, 121-130, 2005.

Laudon, H., Westling, O., and Bishop, K.: Cause of pH decline in stream water during spring melt runoff in northern Sweden, Can. J. Fish. Aquat. Sci., 57, 1888-1900, 2000.

Laudon, H., Westling, O., Löfgren, S., and Bishop, K.: Modeling preindustrial $\mathrm{ANC}$ and $\mathrm{pH}$ during the spring flood in northern Sweden, Biogeochemistry, 54, 171-195, 2001.

McCormick, J. H. and Leino, R. L.: Factors contributing to firstyear recruitment failure of fishes in acidified waters with some implications for environmental research, T. Am. Fish. Soc., 128, 265-277, 1999.

Mellander, P. E., Ottosson, M., and Laudon, H.: Climate change impact on snow and soil temperature in boreal Scots pine stands, Climatic Change, 85(1-2), 179-193, doi:10.1007/s10584-0079254-3, 2007.

Mellander, P. E., Laudon, H., and Bishop, K.: Modeling variability of snow depths and soil temperatures in Scots pine stands, Agr. Forest Meteorol., 133, 109-118, 2005.

Monteith, D. T., Stoddard, J. L., Evans, C. D., de Wit, H. A., Forsius, M., Høgåsen, T., Wilander, A., Skjelkvåle, B. L., Jeffries, D. S., Vourenmaa, J., Keller, B., Kopacek, J., and Vesely, J.: Dissolved organic carbon trends resulting from changes in atmospheric deposition chemistry, Nature, 450, doi:10.1038/nature06316, 2007.

Munson, R. K. and Gherini, S. A.: Influence of Organic-Acids on the $\mathrm{pH}$ and Acid-Neutralizing Capacity of Adirondack Lakes, Water Resour. Res., 29, 891-899, 1993.

Ottosson-Löfvenius, M. O., Kluge, M., and Lundmark, T.: Snow and soil frost depth in two types of shelterwood and a clear-cut area, Scand. J. Forest Res., 18, 54-63, 2003.

Pastor, J., Solin, J., Bridgham, S. D., Updegraff, K., Harth, C., Weishampel, P., and Dewey, B.: Global warming and the export of dissolved organic carbon from boreal peatlands, Oikos, 100, 380-386, 2003.

Rember, R. D. and Trefry, J. H.: Increased concentrations of dissolved trace metals and organic carbon during snowmelt in rivers of the Alaskan Arctic, Geochim. Cosmochim. Acta, 68, 477489, 2004.

Sayer, M. D. J., Reader, J. P., and Dalziel, T. R. K.: Fresh-Water Acidification - Effects on the Early-Life Stages of Fish, Rev. Fish Biol. Fisher., 3, 95-132, 1993.

Schindler, D. W.: The cumulative effects of climate warming and other human stresses on Canadian freshwaters in the new millennium, Can. J. Fish. Aquat. Sci., 58, 18-29, 2001.

Simonin, H. A., Kretser, W. A., Bath, D. W., Olson, M., and Gallagher, J.: In-situ bioassays of brook trout (Salvelinus-Fontinalis) and blacknose dace (Rhinichthys-Atratulus) in Adirondack streams affected by episodic acidification, Can. J. Fish. Aquat. Sci., 50, 902-912, 1993.

Stieglitz, M., Dery, S. J., Romanovsky, V. E., and Osterkamp, T. E.: The role of snow cover in the warming of arctic permafrost, Geophys. Res. Lett., 30, 1721, doi:10.1029/2003GL017337, 2003.

Tranvik, L. J. and Jansson, M.: Climate change - Terrestrial export of organic carbon, Nature, 415, 861-862, 2002 
Venäläinen, A., Tuomenvirta, H., Heikinheimo, M., Kellomaki, S., Peltola, H., Strandman, H., and Vaisanen, H.: Impact of climate change on soil frost under snow cover in a forested landscape, Climate Res., 17, 63-72, 2001.

Vuorenmaa, J., Forsius, M., and Mannio, J.: Increasing trends of total organic carbon concentrations in small forest lakes in Finland from 1987 to 2003, Sci. Total Environ., 365, 47-65, 2006.

Weiss, R. F.: Carbon dioxide in water and seawater: the solubility of a non-ideal gas, Mar. Chem., 2, 203-215, 1974.
Witters, H. E., Van Puymbroeck, S., Vangenechten, J. H. D., and Vanderborght, O. L. J.: The effect of humic substances on the toxicity of aluminium to adult rainbow trout, Oncorhynchus mykiss (Walbaum), J. Fish Biol., 37, 45-53,1990.

Worrall, F., Harriman, R., Evans, C. D., Watts, C. D., Adamson, J., Neal, C., Tipping, E., Burt, T., Grieve, I., Monteith, D., Naden, P. S., Nisbet, T., Reynolds, B., and Stevens, P.: Trends in dissolved organic carbon in UK rivers and lakes, Biogeochemistry, 70, 369-402, 2004. 